\title{
NEW AND FEW KNOWN SPECIES OF BRACHYURA FROM AMBON
}

$$
\text { by }
$$

\section{R. SEREne and M. K. MoOsA}

The present material corresponds to a part of a collection made in Ambon by the senior author. The collection was made during a survey conducted (September 1970) by the Institute of Marine Research of Indonesia (see Serene 1971) and is deposited in this Institute in Djakarta.

The species studied in the present paper are:

Xanthidae-Pilumninae

Pilumnopeus makianus (Rathbun 1929)

Pilumopeus granulatus Balss 1933

Ocypodidae-Camptandriinae

Camptandrium ambonensis nov. sp.

Grapsidae-Varuninae

Ptychognathus guijulugani Rathbun 1914

Ptychognathus altimanus (Rathbun 1914)

Pyxidognathus granulatus A. Milne Edwards 1878

Parapyxidognathus deianira (De Man 1888)

\section{Sesarminae}

Nanosesarma edamensis (De Man 1887)

Neosarmatium ambonensis nov. sp.

Parasesarma lepidum (Tweedie 1950)

Parasesarma aff. kukenthali

Parasesarma leptosum (Hilgendorf 1869)

Holometopus obesus (Dana 1851)

Labuanium politum (De Man 1887)

Apart from the two new, all other species are recorded for the first time at Ambon; one (Holometopus obesus) corresponds to a rediscovery; generally the other species were previously little recorded and are represented by few specimens in the Museum collections. Such an observation emphasizes the interest of collecting activities devoted to the marine fauna of Ambon. The area is not only the type locality of numerous species, but its rich fauna could allow the national reference collection of Indonesia to reach a standard value equal to that of the Museum of Europe and America. 


\section{PILUMNOPEUS MAKIANUS (RATHBUN 1929)}

Heteropanope makiana, Rathbun, 1929, p. 80, pi. 11, fig. 31, 32. Shen, 1932, p. 103, figs. 59 - 61, pi. 2, fig. 6. - Sakai, 1934, p. 306, fig. 18. 1936, p. 176, fig. 91.

Pilumnopeus makianus, Sakai, 1939, p. 543, fig. 57. — Miyake, 1961, p. 173. _ Takeda and Miyake, 1969, p. 124, fig. lib - e.

Type locality: Shyago, Taiwan.

Type specimen: USNM?

Material - AM 128-129, 1 male of cl: 6.62, cb: 9.24; 1 female of cl: 5.18, cb: 7.24. Loc.: Ambon, mouth of Galala River, on parts of the plateau at low tide, R. Serene coll., 22/9/1970.

Observations. - The species is only recorded from Japan, China, Taiwan. The present record extends its geographical distribution much far East and South.

\section{PILUMNOPEUS GRANULATUS Balss 1933}

(Pl. 2A)

Pilumnopeus serratifrons granidatus, Balss, 1933, p. 34.

Pilumnopeus granulatus, Takeda and Miyake, 1969, p. 127, fig. 12c-f.

Type locality: Fidji Island.

Type specimen: male of cl: 11, cb: 14, Museum Hamburg.

Material - AM 130, female of cl: 9.32, cb: 12.72. Loc: Ambon, mouth of Waleila River, low tide, R. Serene coll. 22/9/1970.

Observation. - The specimen was collected in crevices of tree trunk buried in the mud with specimens of Pyxidognathus granulosus. These brachyuran species when being disturbed will fold their legs against the carapace to form a ball like shape and are also characterized by a very slow motion of their appendages.

The species is recorded from Fidji, New Mecklenburg, and several localities in Japan.

Remarks. - The species of Pilumnopeus needs to be revised before to improve and complement the key of Takeda and Miyake (1969) which covers only 4 of the 12 species included in the genus, by these authors. More accurate illustration and definition of many species are necessary; the male pleopod frequently does not provide sufficient discrepancies between close species like those of the group serratifrons-granulatus-indicus-salomonensis.

The male pleopod of granulatus published by Takeda and Miyake (1969, fig. 12c-f) slightly differs from that of indicus published by the same authors (1969, fig. 2-b). But the male pleopod of indicus published by Barnard (1955, fig. 12) differs from that of indicus of those authors and is closer to that of serratifrons published by Dell (1968, figs. $1-4$ ). 
The male pleopod of a specimen of indicus of the Zoological Survey of India examined by the senior author is close to that of Takeda and Miyake (1969) and seems to indicate that the specimens of Barnard (1955) perhaps belong to serratifrons. The male pleopod of a male granulatus of the Oceonographic Institute of Nhatrang examined by the senior author, also slightly differs from that of granulatus of Takeda and Miyake (1969). The specimen was collected in the crevices of a tree trunk in the mangrove at Cua Be near Nhatrang (Vietnam) like the specimen from Ambon. More observations are needed in the relationship of serratifrons, granulatus and indicum and the position of salomonensis in regard of those species also need to be precised.

\section{CAMPTANDRIUM AMBONENSIS nov. sp.}

(fig. 1-P1. 1)

Material. - AM 81, Holotype, 1 male of cl: 5.2, cb: 4.8, Ambon, mouth of Galala River, at middle low tide in swamps up-stream near by the bridge; R. Serene coll., 24/9/1970.

Diagnosis. - Carapace with spaced pits and short setae. Front faintly bilobed with median concavity, its breadth clearly less than half extraorbital breadth. Orbit large with a sinus on upper border; its breadth nearly equal (a little less) to frontal breadth. Lateral border with two teeth behind extraorbital angle which is strongly salient but not acute; the anterior tooth close to extraorbital angle, the posterior far behind at a level a little beyond the middle of the length of carapace; the teeth separated by deep concavities; postero-lateral border of carapace convex; posterior border straight. The regions indicated by elevations: the most significant being a triangular blunt elevation on the branchial region at the metagastric level; a post frontal ridge divided into two median lobes and two ridges outside reaching tha orbital margin. The chelipeds small; the ambulatory legs densely covered with woollen setae. The third maxilliped and abdomen are those of Camptandrium. In natural condition, a piece of the stem of the pleopod 1 can be seen between the concavity of the margin of the segment abdominal 5 and the sternal cavity in which the abdomen is fitted. The male pleopod 1 is that of the genus Camptandrium, but differs from that of $C$. elongatum.

Situation. - The species is close to elongatum but differs by 1) carapace much shorter. The extraorbital breadth is a little broader than length of carapace; the largest breadth being at the level of the second lateral teeth. On elongatum the extraorbital breadth is much less than the carapace length. - 2) the postfrontal ridge more marked. - 3) the postero-lateral angle of carapace without the long process which exists on elongatum; the posterior border of carapace is straight instead to be marked by a median concavity on elongatum. - 4) the strong tubercle of the branchial region which on elongatum is feable and closer to the border of the carapace. - 5) the pereopods $2-5$ broader and more densely covered with setae. - 6) the male pleopod 1 with the inner branch of 
the distal processes divided into two long lamina instead of the single existing on elongatum; the outer branch being nearly similar in the two species. The male pleopod of elongatum is illustrated (figs. 2-3) for comparison for a specimen of the National Museum of Singapore, NMS. 1965. 7. 15. 35, a male of cl: 5.13, cb: 4.42 .

The genus Camptandrium includes three other species: sexdentatum Stimpson 1858, elongatum Rathbun 1929 and starmuhlneri Pretzmann 1968. The species Camptandrium paludicola Rathbun 1909 was made the type species of ilyograpsus Barnard 1955 and C. anomalum Shen 1935 the type species of Shenius Serene 1971.

The species C. starmuhlneri Pretzman 1968 not illustrated and is unsufficiently described for a single female of cl:5, cb: 5 from New Caledonia. There are several good reasons to consider that starmuhlneri with spines on the anterior border of the meri of the ambulatory legs does not belong to Camptandrium and is perhaps a synonym of Shenius anomalum or Ilyograjisus paludicola.

The new species can be separated from the two others by:

1 - Carapace a little longer than broad. Ambulatory legs short with on the meri a distal acute lobe on posterior border. Male pleopod 1 in Shen (1935, fig. 10B). elongatum Rathbun 1929

- Carapace broader than long

2(1) - Ambulatory legs narrow, long and nearly bare. Male pleopod in Shen (1932, text - fig. 140e). sexdentatum Stimpson 1858

- Ambulatory legs broader and with meri densely covered with long setae. Male pleopod in present paper (fig. 1) ......... ambonensis nov sp.

The suggestion of Guinot and Crosnier (1963) to move Cleistostoma japonica into Camptandrium is hard to accept; the male pleopod of Cleistostoma japonica as illustrated by Sakai (1939, fig. 140a) being very different from those of the species of Camptandrium.

\section{PTyChOGNATHUS GUIJULUGANI Rathbun 1914}

(Pl. II, B, C, D)

Ptychognathus guijulugani Rathbun, 1914, p. 71. - Tesch, 1918, p. 93, pi. 4 , fig. 6 .

Type locality: Guijulugan, Negros Island, Philippines.

Type specimen: USNM. cat. no. 44668.

Material. - AM 100, 1 ovigerous female of cl: 7.44, cb: 8.56; AM 101-109, 11 males, the largest cl: 9.12, cb: 10.44. Loc.: Ambon, mouth of Waleila River, low tide; R. Serene coll., 22/9/1970.

Observations. - The specimens belong to one of the species with a tuft of hair on the outer side of the palm, of the chelipeds and which are: onyx, takahasii, barbatus, johannae guijulugani. $P$. onyx and takahasii are well characterized, the first by the acute inner angle of the carpus of cheliped, the second by the rounded antero lateral teeth of the carapace.

$P$. johannae only known by the holotype (male of cl: 16.3 , cb: 19) 
from Comoro Islands present on the outside of the fixed finger near the tip a "very inconspicuous Y-shaped fringe of short hairs" and "within the spoon of both fingers several small fascicle of hairs", as indicated by Rathbun (1914); it is close to pilosus De Man 1892.

It is to barbatus that guijulugani is the closest. According to Rathbun (1914), the second differs from the first by 1) carapace a little narrower. - 2) front more advance and more deflexed lacking the double row of granules. - 3) third maxilliped with exognath wider, ischognath narrower and lobe of mesognath larger. These characters are less marked on the female, which present a row of short hairs about the end of the fingers. Tesch (1918) notices that on guijulugani also the front is more sinuous, the cheliped (of his single male of cl: 9.3, cb: 10.8) "unusually stout and bulky" ... "palm much inflated", and that the species is a small one; probably he has in mind in regard to barbatus.

Our material identified guijulugani by reference to those authors was compared with a series of barbatus from Christmas Island deposited in the National Museum of Singapore. These specimens belong to a series collected by Dr Gibson Hill in 1939 and identified by Dr M. W. F. Tweedie, but never recorded in literature. The species is not quoted in the list of Brachyura of Christmas Island published by Tweedie (1947).

A closer comparison was made with a small male of barbatus which has nearly the same size as our largest male of guijulugani. The discrepancies mentioned and illustrated by Tesch (1918) about the sinuosity of the frontal margin and the cheliped are the most clear. Never (including in large specimens) the palm of barbatus is so bulky (inflated) and with a so wide gap between the fingers. Also the pereopods 2-5 are comparatively longer and slimmer on guijulugani than on barbatus. As noticed by Rathbun (1914) on the female the inner angle of carpus of cheliped presents a blunt spine.

The series was caught at the mouth of a river of clear water. The species lives under the small stones; (some (specimens were caught a little above the water level, others below where the species is actively swimming from stone to stone.

Rathbun (1914) records 2 males and 2 females, the largest male of cl: 8, cb: 9.3, the largest (ovigerous) female of cl: 8, cb: 9. Tesch (1918) records one male of $\mathrm{cl}: 8.3$, cb: 10.5 from Talaut Island not far off the Type locality. The present record extends more south the geographical distribution of the species.

PTyCHOGNATHUS ALTimANUS (Rathbun 1914)

$$
\text { (Pl. III, A, B) }
$$

Varuna altimana, Rathbun, 1914, p. 70.

Ptychognathus altimanus, Tesch; 1918a, p. 88, pi. 4, fig. 5.

Type locality: Point Jamelo, Luzon, Philippines.

Type specimen: USNM. cat. no. 44558.

Material. - AM 98-99, males, the largest cl: 17.64, cb: 18.12, Loc: mouth of Waleila River, low tide; R. Serene coll., 22/9/1970. 
Observations. - On the male the flat lobe occupying the upper margin of the palm, the long spine of the inner angle of the carpus, the sinus (gap) on the subdistal edge of the fixed finger and the exognath of third maxilliped twice as broad as ischium characterize the species. Like the present specimen, the holotype was collected in a river, but also probably near its mouth.

Rathbun (1914) records one male of cl: 20.7, cb: 21.8 from Luzon adn Tesch (1918) one male of cl: 19.5, cb: 20.25, and a female of cl: 17, cb: 17.5 from Nias, which are maintained in the Amsterdam Zoological Museum. In spite of the rarity of the records it seems that the species has a wide distribution in South East Asia from Philippines to the Indian Ocean shores (Tesch 1918).

Remarks. - The suggestion of Rathbun (1915) accepted by Roux (1917) to include in Varuna, not only altimana but 5 species of Ptychognathus: dentatus, spinicarpus, polleni, affinis and onyx is rejected by Tesch (1918). To the 19 species quoted by Serene (1968) must be added, demani Roux 1917 of which ishii Sakai 1939 is perhaps a synonym.

\section{PyXidognathus A. Milne Edwarws 1878}

Pyxidognathus, A. Milne Edwards, 1878, p. 109. — De Man, 1888, p. 148. - Tesch, 1918a, p. 95. - 1918b, p. 167.

Hypsilograpsus, De Man, 1879, p. 72. - 1883, p. 159.

Type species: Pyxidognathus granulosus A. Milne Edwards 1878.

Type locality: Ovalau Island.

History. - De Man (1888) himself establishes the synonym of his Hypsilograpsus with the genus of A. Milne Edwards and of $H$. deldeni De Man 1879 with P. granulosus A. Milne Edwards 1878.

The key of Tesch (1918b) clearly demonstrates that of the four species of the genus granidosus A. Milne Edwards 1878, subglobosus Tesch 1918, deianira De Man 1888 and fluviatilis Alcock 1900, the last two belong to a different group. Ward (1941) for these species establishes Parapyxidognathus with deianira as Type species. Pyxidognathus A. Milne Edwards 1868 s. rest, contains only granulosus; the identity of subglobosus with granidosus being demonstrated further.

The two genera Pyxidognathus and Parapyxidognathus are characterized by the presence of acute granules or spines on the posterior border of meri of pereopods 2-5. Such a character exists at least on three other

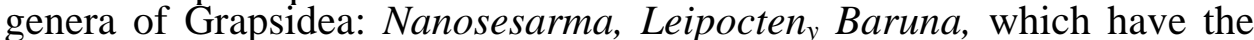
same habitat in the vegetal detritus of the estuarine area. Generally they are collected on trunk of wood under decomposition. Leipocten (and probably also Baruna) have in common with Pyxidognathus (and Pilumnopeus) a very slow motion.

Tesch suggested to link the broadness of the carpi of pereopods with some adaptation to swimming. The present specimens of Pyxidognathus collected in tunnel dug out from trunk of trees, move very slowly and when disturbed being will fold their legs around the carapace, taking the shape of a round ball like already mentioned for Pilumnopeus. Para- 
pyxidognathus deianira with its much longer legs ornamented of long setae was collected at the surface of the mud; it is possible that the dense fringes of setae allow it to swim on soft mud, but it is hard to accept some similarity with the Portunidae, mentioned by Tesch (1918). The remark of Tesch (1918) is however more valid for the genera Varuna and Ptychognathus which are very active swimmers.

PyXidognathus gRANUlosus A. Milne Edwards 1878 (PI. IIIC, D; IVA, B, C, D)

Pyxidognathus granulosus, A. Milne Edwards, 1878, p. 109. - De Man, 1892, p. 317. - Tesch, 1918b, p. 168, pi. 11, fig. 2. - Ward, 1941, p. 39 (under Parapyxidognathus).

Hypsilograpsus deldeni, De man 1879, p. 72. — De Man 1883 p. 159.

Pyxidognathus subglobosus, Tesch, 1918b, p. 170, pi. 11, fig. 1.

Type specimen: Paris Museum? Type locality: Ovalau Island.

Material - AM 110, male of cl: 13.94, cb: 15.38; AM 111, ovigerous female of cl: 15.32, cb: 17.64 AM 112-114, 2 ovigerous females, the largest cl: 11.00 , cb: 11.70, and 1 male of cl: 7.76, cb: 8.40; Loc: Ambon, mouth of Waleila River, low tide; R. Serene coll., 22/9/1970.

Remarks. - The largest ovigerous female agrees with the Type specimen of deldeni (= granidosus) as it is redescribed by Tesch (1918) and the largest male with the Type specimen of subglobosus as it is described by Tesch (1918). The Type specimen of deldeni is a female of cl: 18.5, cb: 22.25 and that of subglobosus a male of cl: 16.5, cb: 18.5 . Tesch (1918) establishes subglobosus by referring to the comparison of these two specimens and there is no doubt that subglobosus is only a male of granidosus.

The present material demonstrates that the discrepancies described by Tesch (1918) to separate subglobolus from granulosus only corresponds to the sexual dimorphism; the male are much less granular and with carapace less strongly vaulted dorsally.

A. Milne Edwards (1878) described the species for a male of cl: 14, cb: 19 from Ovalau Island. De Man (1879) records a single female from Menado (Indonesia) which he himself (1883) establishes as a synonym of granulosus. De Man (1892) records the species at Flores (Indonesia), Tesch (1918) re-examines the female of De Man (1879) and describes as type of subglobosus a male of cl: 16.5, cb: 18.5 from Nias (west of Sumatra) in the Indian Ocean. Ward (1941) when establishing Para.pyxidognathus mentions his examination of a male of granulosus from a fresh or brackish water stream in Fidji, which is housed in the Macleay Museum in Sydney. 


\section{PARAPYXIDOGNATHUS Ward 1941}

Parapyxidognathus, Ward, 1941, p. 39.

Type species: Pyxidognathus deianira (De Man 1888)

Type locality: Mergui Archipelago.

History. - Ward (1941) separates the genus from Pyxidognathus by five characters and several others can be given as is demonstrated by comparing our illustrations.

Parapyxidognathus Ward 1941 contains deianira (De Man 1888) and fluviatilis (Alcock 1900). P. fluviatilis is only known by the Type specimen, a female of cl: 15, cb: 19 from Jessor, India.

\section{PARAPYXIDOGNATHUS DEIANIRA (De Man 1888)}

(PL VA, B)

Pyxidognathus deianira, De Man, 1888, p. 148, pi. 10, figs. 4 -6. Alcock, 1900, p. 407. — Tesch, 1918b, p. 173, pi. 11, fig. 3. - Kemp, 1918, p. 233.

Parapyxidognathus deianira, Ward, 1941, p. 39, figs. 29, 30.

Type specimen: Zoological Survey of India? Type locality:

Mergui Archipelago.

Material - NMS. 1970. 10.26. 1-2, males, the largest cl: 6.64, cb: 8.68; AM 115 -120, 5 males, the largest cl: 6.64, cb: 8.58, 1 ovigerous female of cl: 3.74, cb: 4.90, 2 females, the largest cl: 5.32, cb: 7.38; Loc.: Ambon, mouth of Waleila river, low tide; R. Serene coll., 22/9/1970.

Observations. - The spines on the posterior border of meri of the pereopods 2 - 5 are more developed on the pereopod 5; where four spines can be counted, one nearly submedian being the largest, two in the proximal half and one subdistal. On the other pereopods there are only 2 - 3 subdistal, the first being strongly the largest but no indication of the proximal one exists. On the female the conditions are identical with those of the male but on the posterior margin of the posterior border of pereopod 5 some smaller subsidiary (intercalated) spines also exist, like illustrated by De Man (1888) ; a row of acute granules markes the anterior margin of the posterior border and a spine also exists on the ischium. The palm of cheliped is swollen only on the largest males. On those specimens also, the longitudinal granular rim which exists on smaller specimens is worn out.

The Type specimens are a female of cl: 9, cb: 12.5 and a smaller male. Tesch (1918) recording a larger male of $\mathrm{cl}$ : 10.25, cb: 13.5 from Batavia Bay improved the definition of the species by De Man (1888). Kemp (1918) records a single specimen from Patani River (Thailand). Ward (1941) records 87 males of 4 to 12 as size and 70 females of 4 to 10 from the Gulf of Davao, Philippines. 


\section{NANOSESARMA EDAMENSIS (De Man 1877)}

Sesarma edamensis, De Man, 1887, p. 657. - 1888, p. 379, pi. 16, fig. 5. _ Tesch, 1917, p. 147.

? Sesarma edamensis, Tweedie 1950a, p. 346.

Nanosesarma edamensis, Tweedie, 1950b (in key) p. 312.

Nanosesarma (Beanium) edamensis, Serene and Soh, 1970, p. 405.

Type locality: Edam Island, Djakarta Bay, Indonesia. Type specimen: Leyden Museum.

Material. - AM 131, 1 male of cl: 4.78, cb: 6.72; Loc: Ambon, mouth of Waleila river, low tide; R. Serene coll., 22/9/1970.

Observations. - The specimen has 13 dactylar tubercles on the cheliped and fully agrees with the description of De Man (1888). The specimen of Tweedie (1950a) with a larger number of dactylar tubercles probably belong to another species and we are inclined to consider that edamensis is only known by the type material: a male of cl: 4.75 , cb: 6.75 and a female of cl: 5.20 , cb: 8.20 . The present record extends the distribution of the species at the Eastern Indonesia.

\section{NEOSARMATIUM AMBONENSIS nov. sp.}

(Pl. VC. D)

Material - Holotype, AM 87, 1 male of cl: 8.98, cb: 11.28; Paratypes, AM 88-97, 17 males, the largest cl: 9.58, cb: 11.72; 1 ovigerous female of cl: 8.82, cb: 10.96, 5 females, the largest cl: 9.08 , cb: 11.44 , as in Holotype; Loc.: Ambon, swamps along Waleila river mouth, low tide; R. Serene coll., 24/9/1970.

Diagnosis. - Carapace smooth and punctate, broader than long. Lateral side nearly parallel with a large tooth behind extraorbital angle and a second very feable. Frontal border nearly straight, postfrontal lobes faintly indicated. Posterior border of carapace straight and narrower than front. Frontal breadth clearly more than half extraorbital breadth and largest breadth of carapace (between the first antero-lateral teeth). Upper border of palm of male cheliped with a fine granular rim on outer and 1-2 discontinuous on inner side. Inner surface of the palm with a prominent vertical granular ridge. Upper border of dactylus with four blunt tubercles; fingers with a gap. Pereopods 2 - 5 with meri broad and ornamented with short transverse striae; its anterior border convex with a subdistal spine; carpi and propodi furnished with setae. Male abdomen with telson as long as broad at base; segment 6 a little shorter than telson and exactly twice as broad at base than long.

Situation. - The species by its small size differs from all other species of Neosarmatium, listed by Serene and Soh (1970). It belongs to the group of species which have a (finely granular) rim running longitudinally at the outer limit of the upper border of the palm of the cheliped, recalling the pectinated rim existing at the same place on Metagrapsus A. Minle Edwards. 
By this character ambonensis is close to punctatum A. Milne Edwards 1873, a species only and little accurately illustrated by A. Milne Edwards (1873, pi. 17, fig. 2). Our material of ambonensis was compared with a specimen of punctatum a male of $\mathrm{cl}$ : 16, cb: 20 from Labuan, identified by Tweedie (1950) and maintained in the National Museum of Singapore. The new species differs from punctatum by: 1) the shape of the male cheliped; it has four blunt elongate dactylar tubercles instead of the two strong and acute existing on punctatum; the granular vertical crest of the inner surface of the palm is more prominent; the fixed finger is without the strong carina running parallel to and near the toothed edge of punctatum; the two fingers are more widely gaping. - 2) The postfrontal lobes much less marked and the supra-orbital border more oblique. - 3) the carapace narrower. On punctatum the posterior border of the carapace is as long as the front and the front is as long as half the largest breadth of carapace. The ratio cb: $\mathrm{cl}$ is 1.20 on ambonensis and 1.25 on punctatum. - 4) the male abdomen with telson shorter and segment 6 broader; on punctatum the segment 6 is 1.37 as long as broad at base instead of twice on ambonensis.

$N$. rotundifrons (A. Milne Edwards 1868) the single other species with four dactylar tubercles is illustrated by Tesch, (1917, figs. 6, 7, 8) under the name of fryatti and revised by De Man (1929). However by courtesy of Dr Holthuis, photographs of the type specimen of fryatti established by the Leyden Museum were provided to the senior author. $N$. rotundifrons differs from ambonensis by: 1) the shape of the male cheliped; there is no indication of the granular longitudinal rim on the outer limit of the upper border of the palm; the/ distal of the four dactylar tubercles is situated nearly at half course of the dactylus instead to be much more subdistal on ambonensis; the two fingers are more widely gaping. - 2) the postfrontal lobes much more marked. - 3) the frontal anterior margin more sinuous with a marked median concavity, which is hardly indicated on ambonensis. - 4) the absence of the second anterolateral teeth clearly indicated on ambonensis. - 5) the male abdomen narrower, with segment 6 length 1.30 its breadth at base instead of twice on a?nbonensis. - 6) a smaller size.

\section{PARASESARMA LEPIDIUM (Tweedie 1950)}

Sesarma lepida, Tweedie, 1950b, p. 351, fig. a, b, 2e.

Type locality: Labuan.

Type specimen: British Museum.

Paratypes, Singapore National Museum.

Material - AM 173 - 179, 3 males, the largest cl: 7.42, cb: 9.46; 3 ovigerous females, the largest cl: 6.93, cb: 8.92; 1 female cl: 6.78, cb: 9.18; Loc.: Ambon, mouth of Galala river, in front of the bridge; R. Serene coll., 22/9/1970. 
Observations. - The species is characterized by its number (17 -18) of dactylar tubercles, the absence of subdistal spine on upper border of merus of cheliped, the long dactyli of the pereopods $2-5$ and a male pleopod with a long chitinuous distal process.

Tweedie (1950) records a series of thirty-nine specimens from the type locality, the male cotype with $\mathrm{cl}: 8.7, \mathrm{cb}: 11$. It is the second record which extends the geographical distribution to Eastern Indonesia.

\section{PARASESARMA KUKENTHALI De Man 1902}

Sesarma (Parasesarma) calypso kukenthali, De Man, 1902, p. 534. Tesch, 1917, p. 141 (no material). - Roux, 1917, p. 621.

? Sesarma (Parasesarma) calypso, Nobili, 1899, p. 514.

Type locality: Halmahera.

Type specimen: ?

Material. - AM 145, 1 male of cl: 11.78, cb: 14.58; Loc.: Ambon, swamps along Waleila river mouth, low tide; R. Serene coll., 24/9/1970.

Observations. - The species is separated from calypso by the absence of the prominent granular rim on the inner surface of the palm and the smaller number of dactylar tubercles; such discrepancies justify the specific level.

In his synonymy (for kukenthali) De Man (1902) quotes the material of Sesarma calypso of Nobili (1899) and that of Lanchester (1900) ; those authors mentioning on their specimens a number of dactylar tubercles smaller than calypso. This character is common to 2 or 3 species close to calypso. Tweedie (1936) established lanchesteri for the specimens of Lanchester (1900) ; the species being also characterized by a marked indication of an anterolateral teeth and the presence of 3 obliquely transverse pectinated crests on the upper border of the palm of cheliped. It has like calypso, a transverse row of granules on the inner surface of the palm. The specimen of Nobili (1899) with also dactylar tubercles could belong to lanchesteri as well as to kukenthali.

The species is only known by the type material, 2 males of cl: 14 , cb: 17.5 and cl: 7.75 , cb: 10 and 1 female of cl: 16 , cb: 20.5 from Halmahera and 11 males and 4 females from Merauke recorded by Roux (1917).

\section{PARASESARMA . AFF. KUKENTHALI}

Material. - AM 191, male of cl: 9.74, cb: 12.06; Loc.: Ambon, swamps along Waleila river mouth, low tide; R. Serene coll., 22/9/1970.

Observations. - The specimen is close to kukenthali by having nine dactylar tubercles and no granular ridge on the inner surface of the palm. However the dactylar tubercles are nearly symmetrical without the transverse striae marking the long proximal slope on kukenthali. It is also characterized by the cheliped clearly unequal, the right larger with a palm more swollen and the eyepeduncles remarkbably stouter. 


\section{PARASESARMA LEPTOSOMUM (Hilgendorf 1869)}

Sesarma leptosoma, Hilgendorf, 1869, p. 91, pi. 6, fig. 1. - De Man, 1887, p. 645 (no record). — 1889, p. 436, pi. 10, fig. 11. - Pfeffer, 1889, p. 31. - Ortmann, 1894, p. 725.

Sesarma (Parasesarma) leptosoma, De Man, 1902, p. 534. - Nobili, 1905, p. 497. - Rathbun, 1910, p. 309, pi. 4, fig. 1. — Tesch, 1917, p. 169.

? Sesarma (Holometopus) limb eiisis, Rathbun, 1914, p. 79. - Tesch, 1917, p. 169, 237.

Type locality: Zanzibar.

Type specimen: ?

for limbensis, Type locality: Limbs Island, Philippines;

Type specimen: USNM no. 120.523.

Material - AM 193-195, 7 females, the largest cl: 9.72, cb: 11.36; 2 ovigerous females, the largest cl: 8.5S, cb: 9.66; Loc.: Ambon, Waleila river mouth, low tide; R. Serene coll., 22/9/1970.

Observation. - All specimens being females cannot provide information on the number of the dactylar tubercles. The species however is well characterized by the propodi remarkably long and narrow and the dactyli remarkably short, on the pereopods $2-5$ (mainly 4,5).

$S$. (H.) limbensis is identical with the material from the Indo Malayan region identified as leptosomum, referring to the comparison made by the tsenior author between specimens of leptosomum of the National Museum of Singapore from Kuantan, Malaysia (identified by Dr Tweedie but not recorded in literature) and a paratype of limbensis (a female of cl: 12, cb: 13.5).

The single type specimen of leptosomum is a female. De Man (1899) describing a male, mentions the presence of oblique crests on the upper surface of the palm, with reference to this character the species was further classified as a Parasesarma. Rathbun 1914) describing limbensis as Holometopus mention "2 or 3 granulated lines" on the upper surface of the palm." The classification of the species into Holometopus or into Parasesarma request further observations, but the identity of limbensis with leptosomum let little doubt.

The species described from East Africa (Hilgendorf, Pfeffer) is recorded from the Fidji (De Man, Ortmann, Tesch), Halmahera (De Man), New Guinea (Nobili, Rathbun), Philippines (Rathbun), Malaysia.

HolOMETOPUS OBESUS (Dana 1851)

$$
\text { (Pl. VIA, B, C) }
$$

Sesarma obesum, Dana, 1851, p. 250. - 1852, p. 356, pi. 22, fig. 10. De man, 1887, p. 643.

Type locality: Balabac Island, the Philippines.

Type specimen: lost.

Material. - AM 229-231, 1 male of cl: 10.96, cb: 12.24; 1 ovigerous female of cl: 10.52, cb: 11.62; 1 female of cl: 7.78, cb: 8.38; Loc: East coast of Ambon, swamps near road; R. Serene coll., 28/9/1970. 
Observations. - The specimens agree with the relatively brief description of Dana (1852). The upper border of dactylus of cheliped presents a longitudinal row of $8-9$ small round granules regularly distributed all along and a row of 2 - 3 on the inner side at the proximal part. The outer surface of the palm is perfectly smooth; the median part of the inner surface is swollen and ornamented with same acute granules not arranged in line. The anterior border of merus distally is regularly convex like habitual on Holometopus and there is no subdistal spine on upper margin of the merus. The dorsal surface of the carapace is shagreened. The color is violet with the cheliped orange.

The species by its antero-lateral border "without acute margin but rounded except close to the anterior angle (Dana)" is close to Metasesarma aubryi. A comparison was made with specimens of aubryi of the National Museum of Singapore mainly NMS. 1966. 12. 21.1, a male of cl: 11.04, cb: 12.92. The two forms clearly differ at least by the condition of the orbital hiatus, which on aubryi is close, the infra lower orbital angle crossing over the frontal margin. On Holometopus obesus, the flagellum of antenna is very small and its extremity just reaches the orbit; the infra lower orbital angle is well marked by a triangular process but the orbital hiatus is widely open, greatly occupied by the antero-lateral process of the basal antennal joint. Besides the species differs by numerous other characters. The relation to dehaani indicated by De Man (1887) seems to be related to the front; the two species differ by many characters and among them obesus has a much smaller size.

The species has some relationship with Sesarma faciatum Lanchester 1900 a species presently hard to classify into Holometopus having a feably indicated lateral tooth behind the extraorbital angle and two faint granular (not pectinated) oblique rim on the upper surface of the palm. Other characters of fasciatum are those of Holometopus. The two species obesus and fasciatus clearly distinct from one another perhaps are congeneric; they have the same aspect, same color, same habitat (in the grass of the banks of mangrove swamps). Their detailed comparative study would probably assist to improve the present unsatisfactory position of fasciatum into Parasesarma, Chiromanthes or Holometopus.

Dana $(1851,1852)$ described the species for a male of cl: 14, cb: 15 from Balabac Straits and the present record is a rediscovery.

\section{LABUANIUM POLITUM (De Man 1887)}

Sesarma polita, De Man, 1887, p. 654. - 1888, p. 189, pi. 13, fig. 7-9. - Alcock, 1900, p. 422 (De Man's specimen). — Kemp, 1918, p. 246. - Tweedie, 1940 , p. 93. - 1950b p. 346, figs. 2c, 3a - d.

Labuanium politum, Serene and Soh, 1970, p. 392, 410, pi. 7C, D.

Type locality: Sulliwan Island, Mergui Archipelago.

Type specimen: Zoological Survey of India. Cotype: Leyden Museum.

Material. - AM 82-86, 3 males, the largest cl: 40.62, cb: 36.72; 1 female cl: 39.22, cb: 35.28; Loc.: Ambon, swamps along Waleila river mouth; R. Serene coll., 24/9/1970; low tide. 
Observations. - The species is described from the Mergui Archipelago for 4 males and 2 females. Kemp (1918) records 3 specimens from Thailand. Tweedie (1936) one from Johore and Tweedie (1950) 3 males and 3 females from Labuan. The present record extends its geographical distribution to Eastern Indonesia. The species inhabits the trunks of the nippa palm and it is possible that its geographical distribution corresponds with the distribution of those plants.

\section{ACKNOWLEDGEMENTS}

The study was conducted in the National Museum of Singapore with optical and photographic equipment of Unesco. We expressed our gratitude to Mr. Eric R. Alfred, Acting Director of the National Museum of Singapore, who provides us with many curatorial facilities and gives us free access to his collections.

The drawings are of Mr M. Kasim Moosa. The photographs of pl. 1; pl. 2B, C, D; pl. 3A, B, C, D; pl. 5A, B; pl. 6A, B, C are of Mr M. Kasim Moosa; those of pl. 2A; pl. 4A, B, C, D; pl. 5C, D; pl. 6D are of Dr Raoul Serene. The drawings and photographs are made with a Projectina.

Alcock, A. W., 1900. Materials for a carcinological fauna of India, No. 6. The Brachyura Catometopa of Grapsoides. J. A. S. Bengal, 69, (2), 3, pp. 279-486.

BALss, H., 1933. Beitrage zur Kenntnis der Gattung Pilumnus (Crustacea Decapoda) und verwandter Gattungen. Capita Zoologica, -4, (3), pp. 1-47, figs. 1-7, pis. 1-7.

BARNARD $^{\wedge}$ K. H., 1955. Addition to the fauna-list of South African Crustacean and Pycnogonida. Ann. S. Afr. Mus, 43, (1), pp. 1-107, text-figs. 1-53.

DANA, D.J 1851 Conspectus Crustaceorum quoe in Orbis Terrarium circumnavigatione, Carole Wilkes a classe Reipublicae Faederatae Duce,lexitet descripsit.Dana. Proc. Acad. Nat. Sci. Philad., 5, pp.247-254and267272. 1852. Crustacea in United States Exploring Expedition during the years 1838, 1839, 1840, 1841, 1842, IS, (1), pp. I - VIII and 1-685.

Dell, R. K., 1968. Notes on New Zealand Crabs. Rec. Dominion Mus., 6 (3), pp. 13-18, figs. $1-3$.

Guinot, D. \& CROSNIER, A , 1963. Remarques zur les genres Cleistostoma,Paracleistostoma et Tylodiplax et description de T. derijardi sp. nov., Bull. Mus. Nat. Hist., 2 serie, 35, no. 6, pp. 606 - 619, figs. 1 - 14.

Hilgendorf, P., 1869. Crustacea in: Von der Deckens Reisen in Ostafrika, 3, (1), pp. $69-116$, pi. 1 - 6.

KEMP, S., 1918. Crustacea Decapoda and Stomatopoda Results of a tour in the Far East. Mem. A. S. Bengal, 4, pp. 217-297.

LANCHESTER, W. F.; 1900. On a collection of Crustaceans made at Singapore and Malacca Part I. Crustacea Brachyura. Proc. Zool. Soc. London (1), pp. 719-770, pis $44-47$

. MAN, DE, J. G., 1879. On some species of imperfectly known podophthalmous Crustacea of the Leyden Museum. Notes Leyden Mus. 1, (19), pp. 53-73. ,1883'. Carcinological studies in the Leyden Museum no. 3, Notes Leyden Mus., 5, pp. 150-169.

, 1887. Uebersicht der Indo-pacifischen Arten der Gattung Sesarma Say nebst einer Kritik der von W. Hess und E. Nauck in. den Jahren 1865 und 1880 beschriebenen Decapoden. Zool. Jahrb., 2, pp. 639 - 689, pl. 1. 
MAN, DE,, 1888. Bericht ueber die im Indischen Archipel ${ }^{1}$ von Dr J., Brock gesammelten Decapoden und Stomatopoden. Arch. Naturg. Berlin, 53, pp. 215-600, pis. 7-22a. 1889' Ueber einige neue oder seltene Indo-pacifische Brachyuren. Zool. Jahrb., 4, pp. 409 - 452, 1 litho, 8 pls. 1892. Decapoden des Indischen Archipel in: Max Weber's Zool. ErgenNiederlandisch Ost. Indies, 2 pp. 330 - 351, pls. 19 - 22.

, 1902. Die von Herrn Professor Kukenthal in: Indischen Archipel gesammelten Decapoden und Stomatopoden.

Kukenthal, Ergebnisse einer Zoologischen Forschungsreise in den Molukken und Borneo. Abh. Senck. Naturg. Ges. 25, 3, pp. 465 -929,. pls. $19 f-27$.

MiYAKE, S., 1961. A list of the Decapod Crustacea of the Sea of Ariake, Kyushu. Rec. Oc. Works. Special no. 5, pp. 165 -178. NoBILI, G., 1899. Contribuzioni alia

conoscenza della fauna carcinologica della Papuasia, delle Molucche e dell' Australia. Ann. Mus. Civ. Stor. Nat. Genova, (2), 20, pp. 473-523.

Sign. , 1905. Decapodi e Isopodi della Nuova Guinea Tedesca raccolti Sdal

Biro. Ann. Mus. Nat. Hungar, 3, pp. 480 -, 507, pis. 12 - 13. OrTmanN, A. E., 1894. Die Decapoden Krebse des Strassburger Museum VIII. Brachyura

III, Catometopa. Zool. Jahr. 7, pp. 683-772, pi. 2»3.

Pfeffer., 1889. Mitt. Naturhist. Mus. Hamburg, 6, p. 31.

PretzmanN, G.? 1968. Eine neue Krabbe d'er Gattung Camptandrium. Ent. Nach. Wien. 15, pp. 16-17.

RAthbuN $^{1}$, M J., 1909. New crabs from the Gulf of Siam. Proc. Biol. Soc. Wash.,22, pp. 107-114.

, 1910. Decapod Crustaceans collected in Dutch East India and elsewhere by Mr Thomas Barbous in 1907. Bull. Comp. Zool. Harvard, 3, (16), pp. 305 - 317, pis. 1-6.

1914. New species of Crabs of the family Grapsidae \& Ocypodidae. Proc. U. S Nat. Mus. U7, no. 2044, pp. 69-85.

, 1924. New species of crabs from Samoa Proc. Biol Soc. Washington, 37, pp. 127-128.

', 1929. New and Rare Chinese crabs. Lignan Science Journal, 8, p. 75 - 104, pis. $3-15$.

Roux. J., 1917. Resultates de TExpeditionscientifiqueneerlandaise a la Nouvelle Guinee. Nova-Guinea, 5, pp. 619 - 630.

SAKAI, T., 1934. Brachyura from the coast of Kyushu. Sc. Rep. Tokyo Bunrika Daigaku, Sect. B, I, no. 25, pp. 281 - 330.

, 1939. Studies on the Crabs of Japan. IV Brachygnatha Brachyrhyncha. Tokyo, pp. 365-741, 129 figs., pis. 42-111.

SERENE, R. 1968. A Check list of the Brachyuran Indo-pacific species in: Prodromus for a Check list of the non-planctonic marine fauna of South East Asia. National Ac. Singapore, Sp. Publ. 1, pp. 33-112.

1971. Observations sur des genres et especes nouveaux ou mal connus de Brachyoures (Decapoda. Crustacea) du Sud East Asiatique. Bull. Mus. Hist. Nat. 42, no-. 5, p. 00 - 00 (under printing).

, and SOH, C.L* 1970. New genera allied to Sesarma Say 1817 (Brachyura. Decapoda, Crustacea) Treubia, 27, (4), pp. 387-416, pis. 1-8.

Shen, C. J., 1932 The Brachyura Crustacea of North China. Zool. Sinica, A, 9 (1), pp. 1-300, 111 text-figs., 10 pis.

, 1935. On some new and rare crabs of the families Pinnotheridae, Grapsidae and Ocypodidae from China. Chinese Journ. Zool. I, pp. 19 - 40, 15 text-figs.

StimpscN, W., 1858. Prodromus descriptionis animalium evertebratorum quae in Expeditione ad Oceanum Pacificum Septentrionalem, a Republica Federata missa, Cadwaladaro Ringold et Johanne Rodgers Ducibus, observavit et descripsit. Part V - Crustacea, Ocypodidae. Proc. Acad Nat. Sci. Philad. 10, pp. 93-100 (39-56). 
TAKedA, M. and MiYake, S., 1969. Pilumnid crabs of the family Xanthidae from the West Pacific. II. Twenty-one species of four genera with description of four new spscies. Occ. Pap Zool Lab. Fac. Agyric, Kyushu Univ., 2, no. 7, pp. 93 -156, figs. 1 - 18.

TESCH, J., 1917. Synopsis of the general Sesarma, Metasesarma, and Cleistocoeloma with a key to the determination of the Indo Pacific species. Zoolog. Med., 3, ( 2 - 3 ), pp. 127-260.

, 1918a. The Decapoda Brachyura of ths Siboga Expedition. Hymenosomidae, Retroplumidae, Ocypodidae, Grapsidae and Gecarcinidae. Siboga-Expeditie, 39c, , pp. 1 - 148, 6 pis.

1918b. The Grapsoid genus Pyxidognathus A. Milne Edwards with description of a new species. Zool. Med., 4-, pp. 167-178, pi. 11.

TweEdie, W. F., 1936. Crabs of the family Grapsidae in the collection of the Raffles Museum. Bull. Raff I. Mus. Singapore, no. 12, pp. 44 - 70, pis. 14 - 15. 1940. New and interesting Malaysian species of Sesarma and Utica. (Crus tacea Brach.). Bull. Raffl. Mus. Singapore, no. 16, pp. 80-113, 1 pi.,12 text-figs.

, 1950a. Notes on Grapsoid Crabs from the Raffles Museum. Bull. Raffl Mus. Singapore, no. 23. pp. 310-324, 1 fig., pi. 7.

1950b. Grapsoid crabs from Labuan and Serawak Serawak Mus. J J., 5, 2, 1950, pp. 338-369, figs. 1-9.

WARD, M., 1941. New Brachyura from the Gulf of Davao, Mindanao, Philippine Islands. Amer. Mus. Nov., no. 1104, pp. 1 -15, 30 figs.

\section{TEXT OF THE FIGURES}

Fig. 1-3: male pleopod 1 of: 1, Camptandrium ambonensis, holotype, male of cl: 4.8, cb: $5.2-2$, 3, Camptandrium elongatum, NM\$., male of cl: 5',18, cb: 4.42 .

\section{TEXT OF THE PLATES}

PL I - Camptandrium ambonensis, Holotype, male of cl: 4.8, cb: 5.2 .

PL II - A, Pilumnopeus granulatus, female of $\mathrm{cl}:$ 9.32,, cb: 12.72. - B, C, D, Ptychognathus guijulugani: B, C, male of cl: 9.06 , cb: $10.68-\mathrm{D}$, female of cl: 7.44, cb: 8.56. PL III - A, B, Ptychognathus altimanus, male of cl: 17.64, cb: 18.12. - C, D,

Pyxidognathus granulosus: C, malte of cl: 13.94 , cb: 15.38 - D, ovigerous female of cl: 17.64 , cb: 15.32 .

PL IV - Pyxidognathus granulosus (same specimen as PI. Ill) : A,third maxilliped. — B, male abdomen. - C, male chelipad. — D, female cheliped.

PL V - A, B, Parapyxidognathus deianira, male of $\mathrm{cl}$ : 6.64, cb: 8.58. - C, D, Neosarmatium ambonensis, holotype. male of cl: 8.98, cb: 11.28.

PI. VI - A, B, C, Holometopus obesus, male of cl: 10.96, cb: 12.24. — D, Metasesarma aubryi, NMS., male of cl: 11.04. cb: 12.92. 
FIGURES $1-3$.
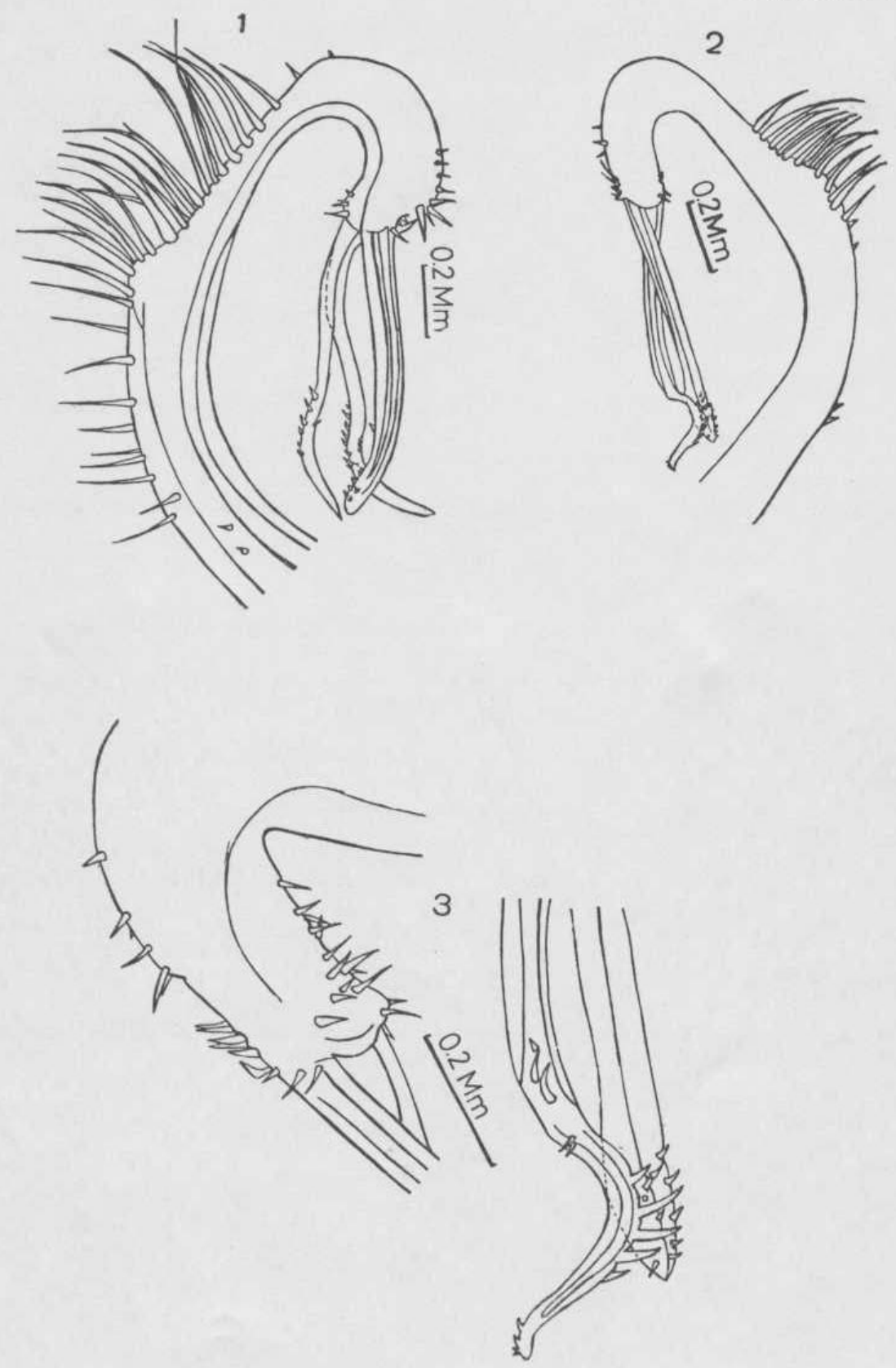
PLATE I

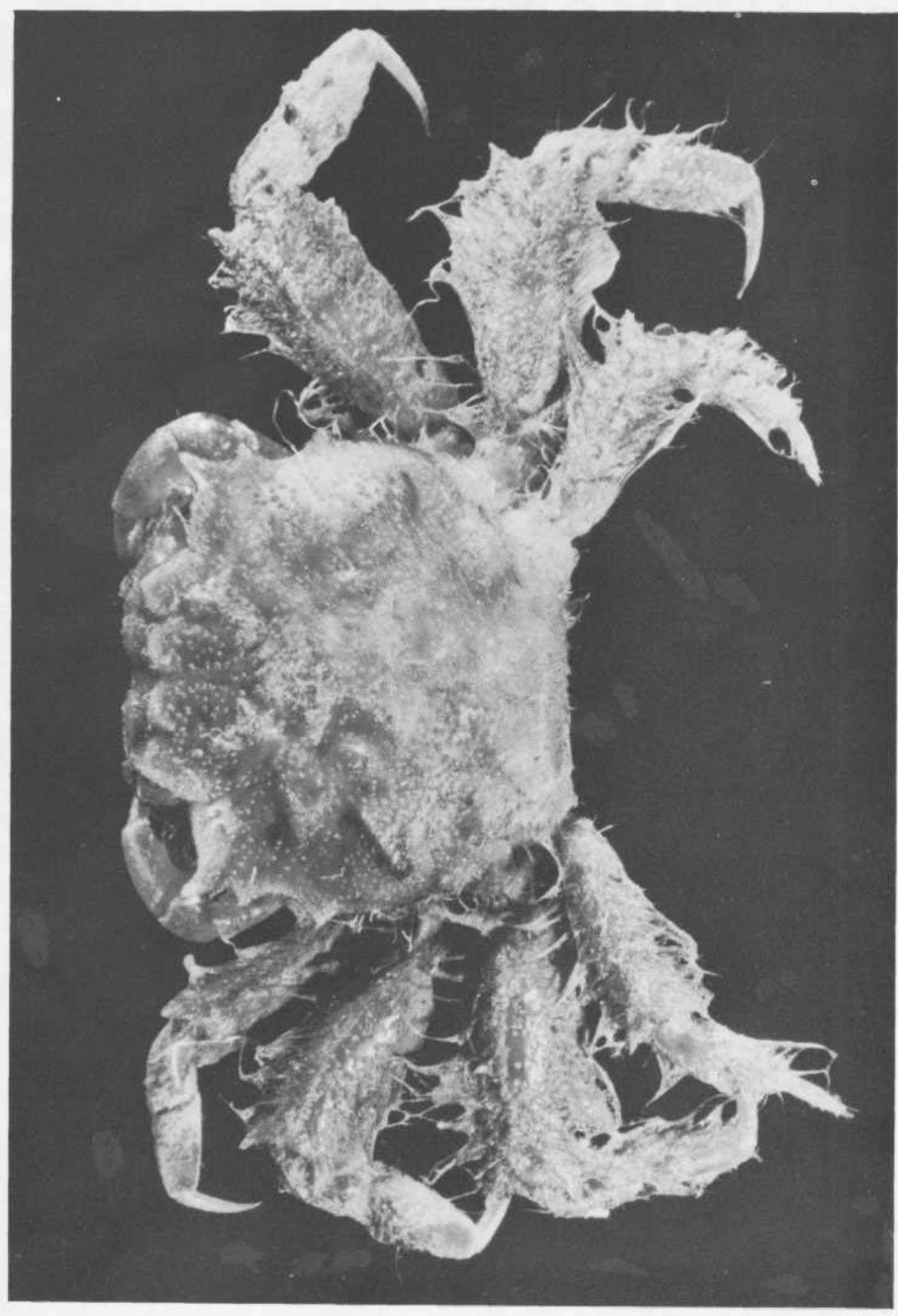


PLATE II
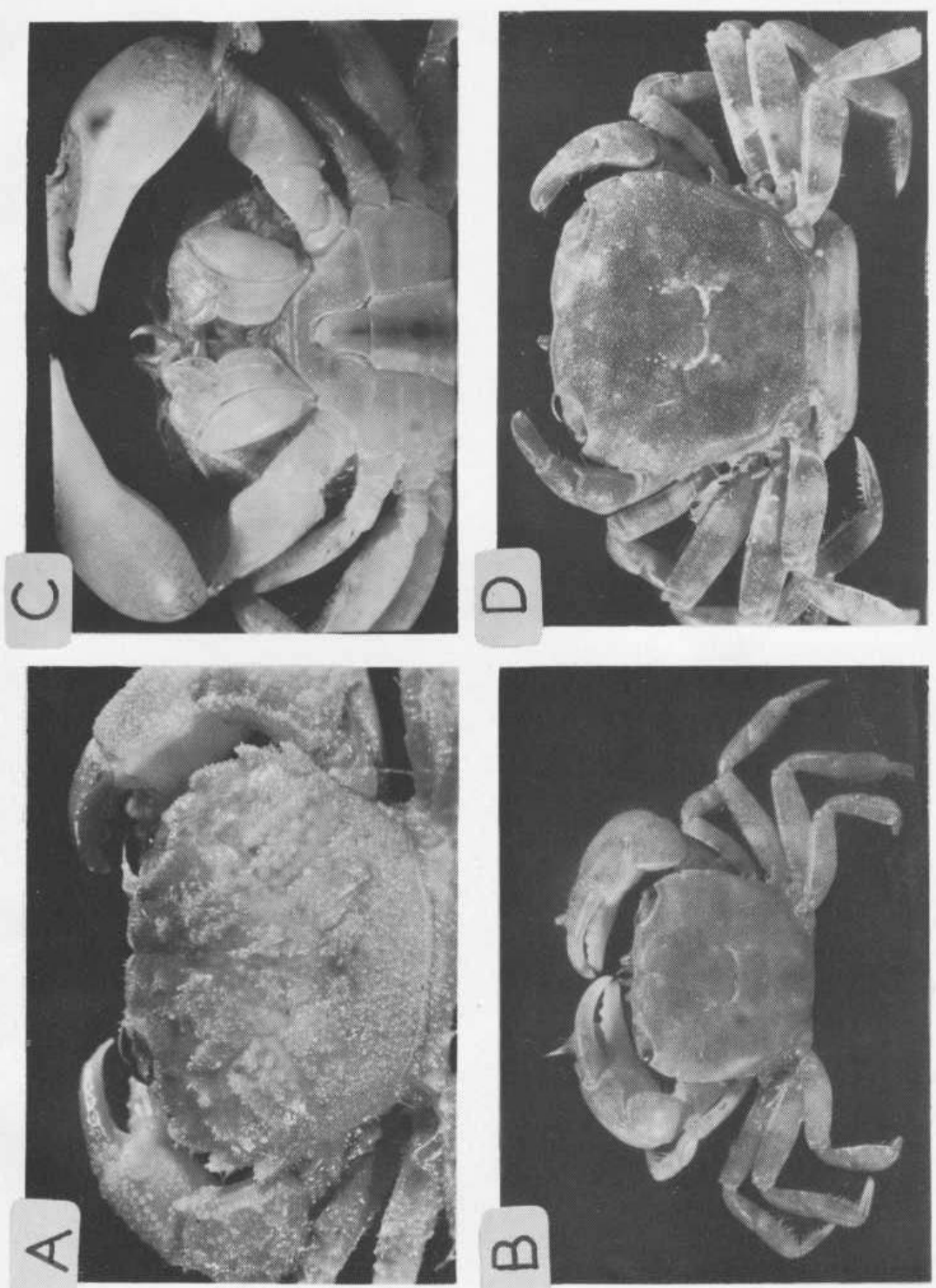
Mar. Res. Indonesia Vol.11, 1971 : 3-24

PLATE III
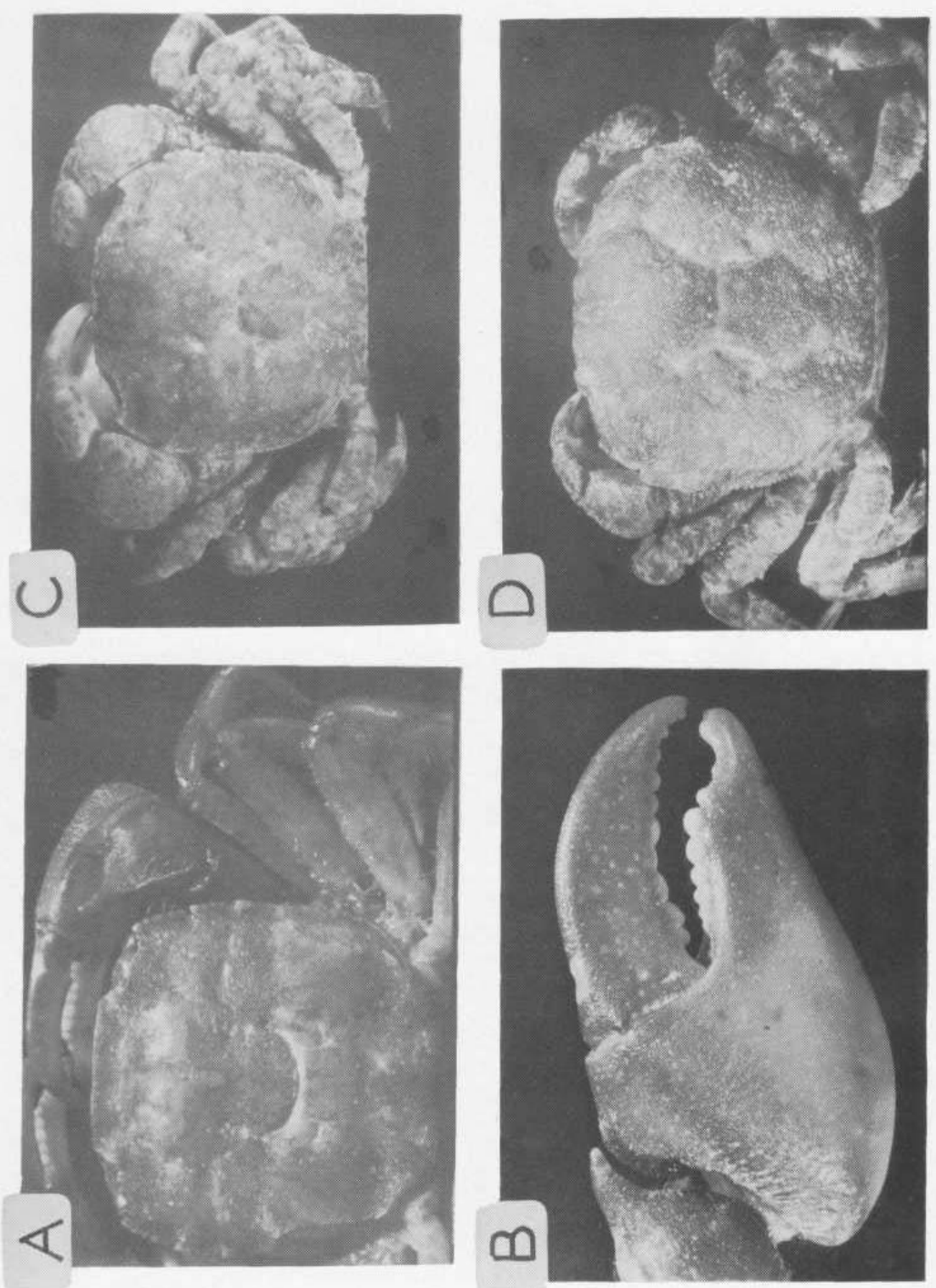
PLATE IV
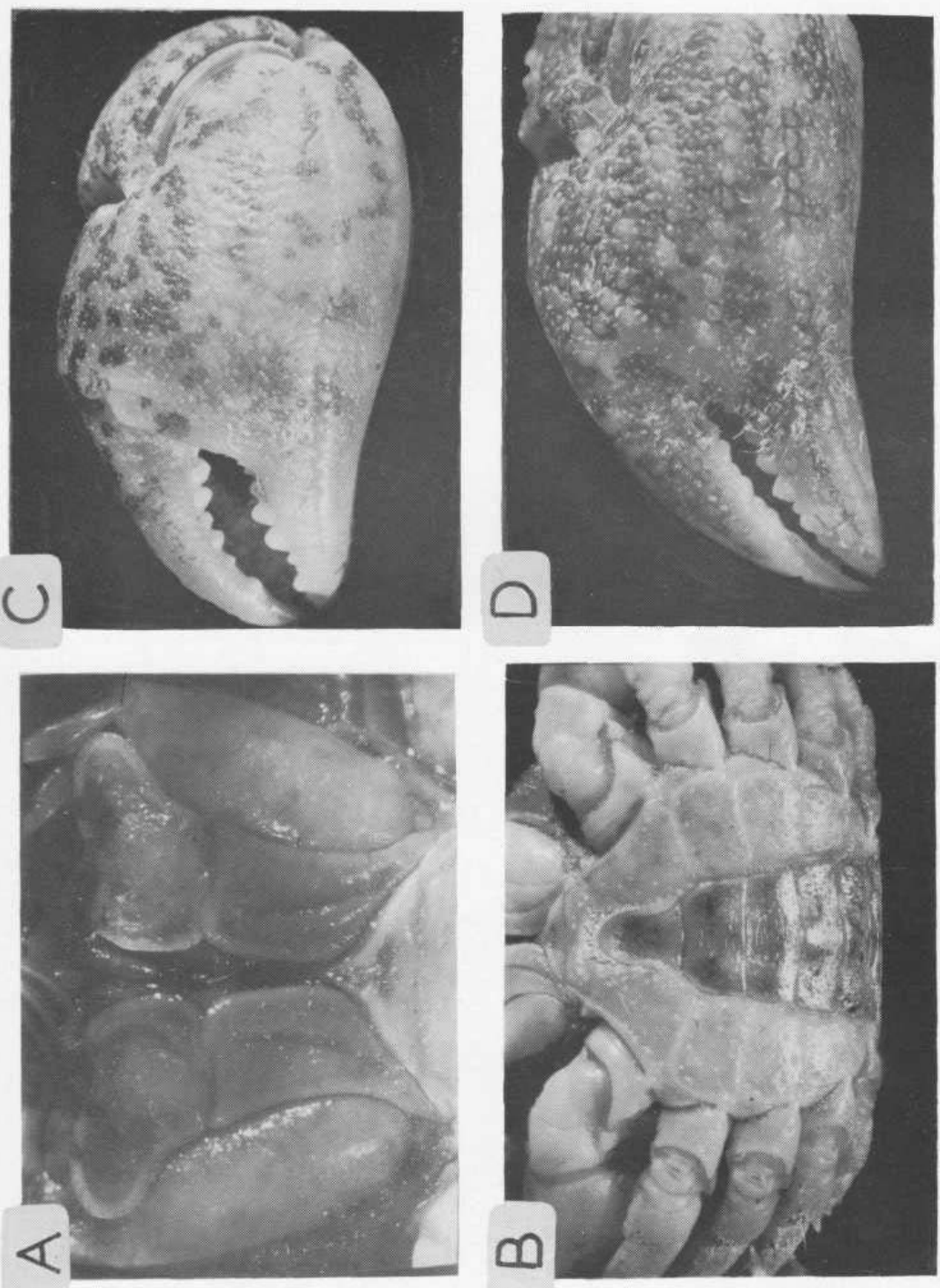
PLATE V
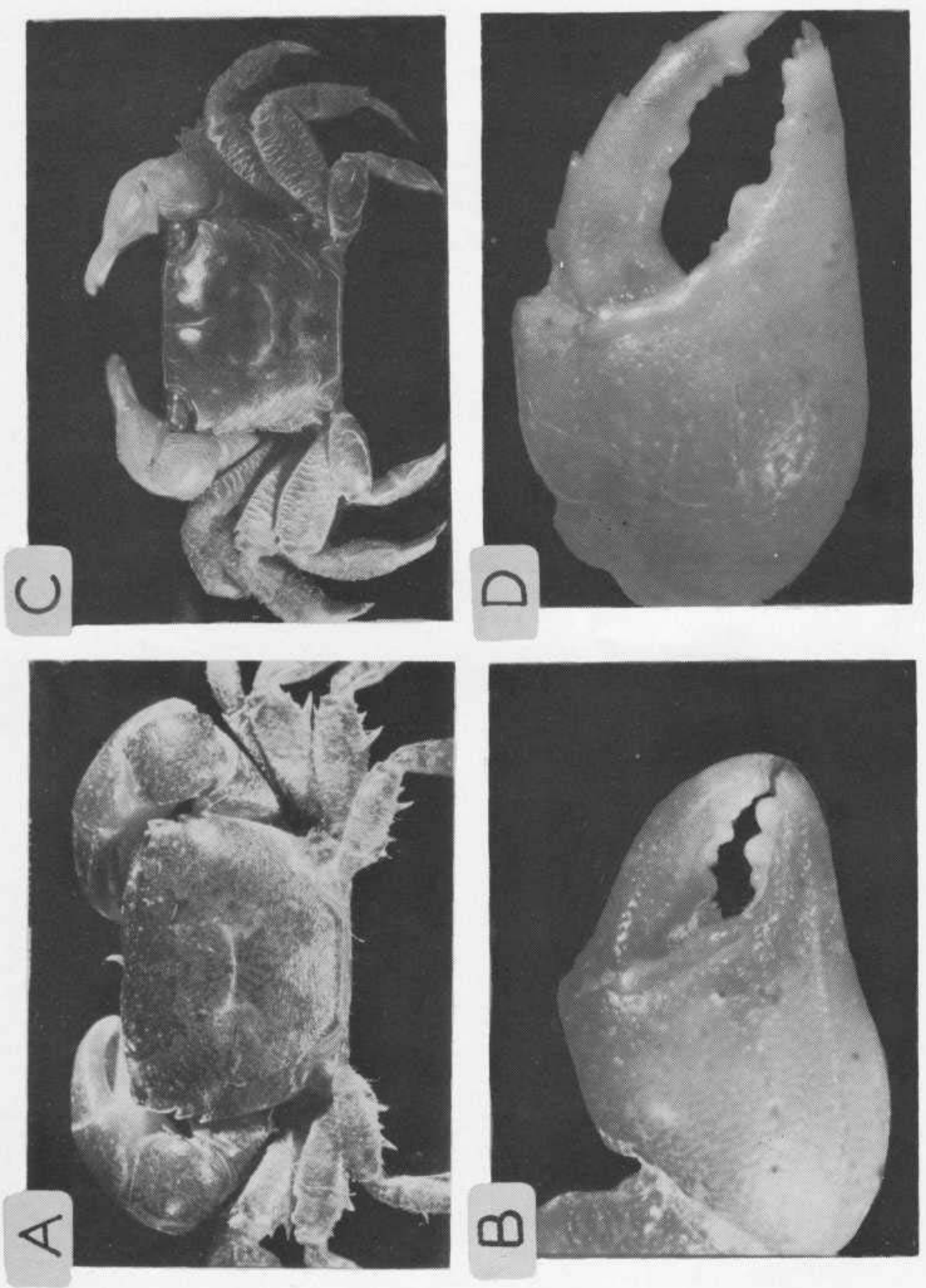


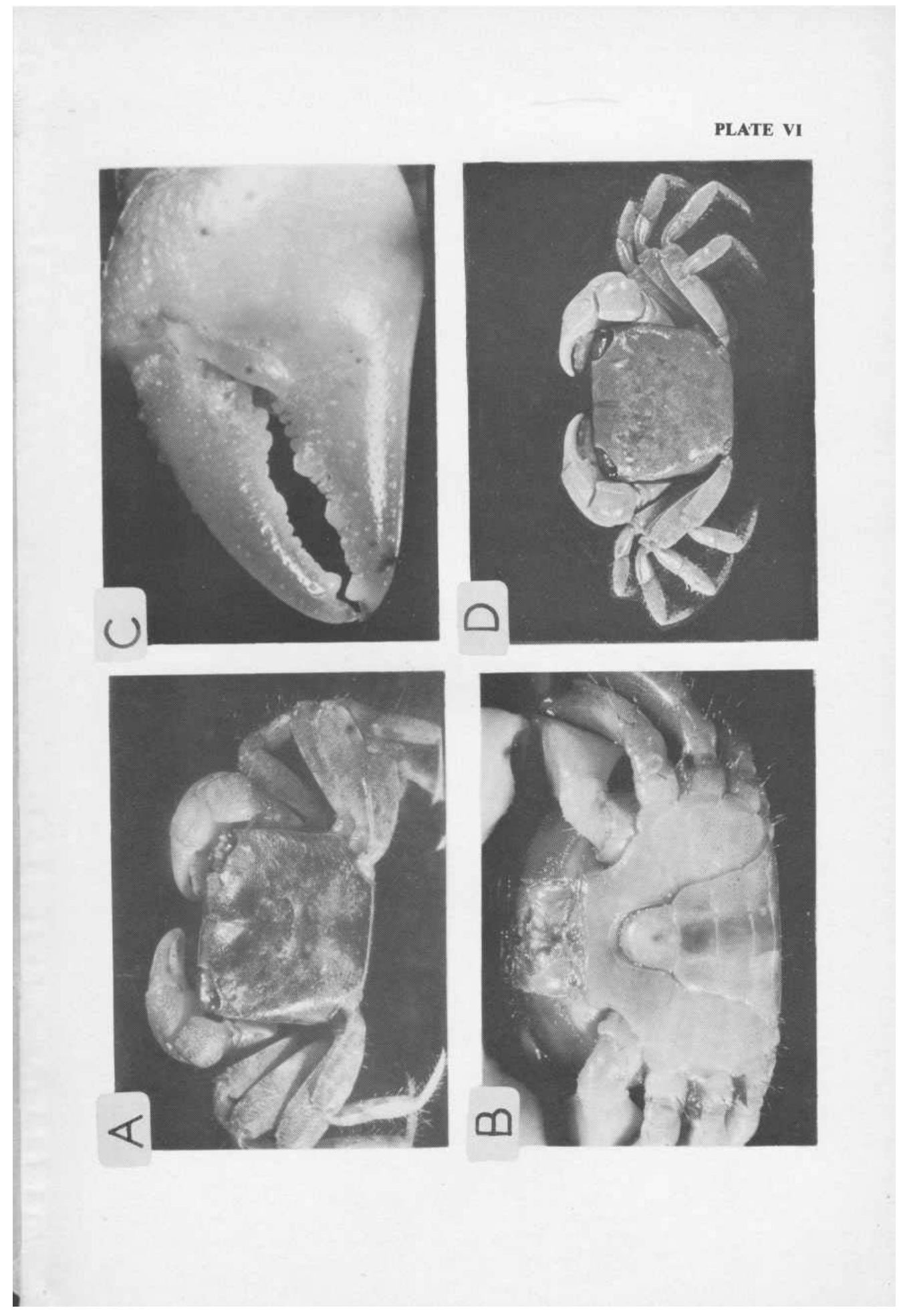

